\title{
Occupational Sex Segregation And Economic Development
}

Paul A. Swanson, (E-mail: swansonp@wpunj.edu) William Paterson University

\begin{abstract}
Occupational sex segregation is an important measure of equality between men and women in the labor force. As men and women share more occupations and increasingly perform the same jobs in the workplace, occupational sex segregation decreases, indicating a more similar work experience between the sexes, as well as an increase in gender equality. In this paper a cross-national examination of $D$, an index of dissimilarity, is presented. Data from the International Labor Organization is used to calculate D for various countries. Using the United Nations' classification of countries into least developed, developing, developed, and Eastern European, this paper examines the effect of economic development on occupational sex segregation.
\end{abstract}

\section{INTRODUCTION}

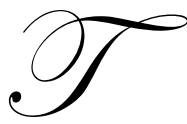

he integration of women into an economy, and their position relative to men in that economy, can be usefully assessed by examining the gender pay gap, female and male labor participation rates (and the related percentage of women in the labor force), and occupational sex segregation. In a previous paper (Swanson 2003) I documented the trends of these labor market outcomes for the United States. In the present paper I extend the analysis to examine these three measures across a number of countries.

The general trend of the integration of women into the U.S. economy is clear. By all three of the above measures, U.S. women have improved in their relative position. The question to be addressed in this paper is whether this is true for other economies. Has the relative economic position of women across the world been improving? Does their position depend on their country's level of economic development?

\section{INTERNATIONAL TRENDS IN THE INTEGRATION OF WOMEN INTO THE ECONOMY}

\section{Gender Gap in Earnings}

The percentage of female to male earnings (median annual income for year-round full-time workers) in the U.S. declined in the post-War period, reaching a low of 56.6\% in 1973 . Since then it has increased almost continuously to a rate of $75.6 \%$ in 2003 (Swanson 2003, p. 41). As one indicator of gender equality, this narrowing of the gender gap shows an improvement in the position of women in the U.S. economy. It also means that women in the U.S. are becoming increasingly integrated into the economy. However, the gap is still significant, and in the last ten years it has been closing more slowly.

We compare this positive trend in the U.S. to other countries in Table 1. Statistics for two years-1990 and 1995/2002--are shown for 35 countries in addition to the U.S. It can be seen that the gender gap declined during that period for 25 countries, while it increased for the other 10 countries. The average of the most recent ratio of women's to men's earnings for all 35 countries is .716, which is somewhat below the 2002 U.S. ratio of .760. The average in 1990 for the 35 countries was .695 , while the U.S. ratio for the same year was a slightly higher .710 . Thus the international trend since 1990 is not quite as favorable as the U.S. trend: women's economic position, as measured by this labor market outcome, while improving in most countries, is not improving at the rate that it is in the U.S. 
Table 1 presents the ratio of women's wages to men's wages for two of the four categories of the U.N. grouping of countries (least-developed, developed, developing, and Eastern European). Eighteen countries listed are classified as developing countries, and 17 are classified as developed market economies. In calculating averages for the gender gap ratio for the two years shown for these two groups we find significant differences. For the developing countries, the 1990 average is 65.5, while the most recent average is 65.6. For the developed countries, the 1990 average is 73.6 and the most recent average is 78.0 .

We see from this that women's pay is much closer to men's pay in the developed economies than in the developing economies. In fact, while it is not an indicator of economic development, the gender gap is an indicator of social development, with the developed market economies being more socially advanced by this indicator. The gender gap in the United States is very similar to that of the developed countries, although is it is considerably wider than it is in Sweden, the developed country with the smallest gender gap in earnings (see Blau and Kahn 2000).

The level of economic development also appears to affect the trend in relative earnings. For the time shown, there has been no movement, on average, in this ratio in the developing countries. Women's pay has remained stagnant at about $2 / 3$ of the level of men's pay for the past ten years. On the other hand, the ratio of women's pay to men's pay has increased $6 \%$, so that women are now paid over $3 / 4$ of what men are paid in the developed countries. Again, the economically developed countries are more socially developed than the developing countries.

Table 1: Women's Wages in Manufacturing as a Percentage of Men's Wages

\begin{tabular}{|c|c|c|c|c|c|c|c|}
\hline \multicolumn{8}{|c|}{ Developing Countries } \\
\hline & 1990 & $1995 / 2002$ & $\Delta$ & & 1990 & $1995 / 2002$ & $\Delta$ \\
\hline Bahrain & 62 & 44 & -18 & Malaysia & 49 & 63 & +14 \\
\hline Brazil & 54 & 61 & +7 & Mexico & 50 & 70 & +20 \\
\hline Costa Rica & 74 & 83 & +9 & Paraguay & 66 & 44 & -22 \\
\hline Cyprus & 58 & 54 & -4 & Republic of Korea & 50 & 56 & +6 \\
\hline Egypt & 68 & 71 & +3 & Singapore & 55 & 61 & +6 \\
\hline El Salvador & 94 & 79 & -15 & Sri Lanka & 88 & 87 & -1 \\
\hline Hong Kong & 69 & 64 & -5 & Swaziland & 73 & 63 & -10 \\
\hline Jordan & 57 & 58 & +1 & Thailand & 64 & 72 & +8 \\
\hline Macao & 67 & 54 & -13 & Turkey & 81 & 97 & +16 \\
\hline & & & & Average & 65.5 & 65.6 & \\
\hline \multicolumn{8}{|c|}{ Developed Market Economy Countries } \\
\hline & 1990 & $1995 / 2002$ & $\Delta$ & & 1990 & $1995 / 2002$ & $\Delta$ \\
\hline Australia & 82 & 89 & +7 & Luxembourg & 62 & 72 & +10 \\
\hline Belgium & 75 & 79 & +4 & Netherlands & 77 & 78 & +1 \\
\hline Denmark & 85 & 86 & +1 & New Zealand & 74 & 80 & +6 \\
\hline Finland & 77 & 81 & +4 & Norway & 86 & 88 & +2 \\
\hline France & 79 & 78 & -1 & Portugal & 69 & 65 & -4 \\
\hline Germany & 73 & 74 & +1 & Sweden & 89 & 91 & +2 \\
\hline Greece & 78 & 82 & +4 & Switzerland & 68 & 72 & +4 \\
\hline Ireland & 69 & 74 & +5 & United Kingdom & 68 & 78 & +10 \\
\hline Japan & 41 & 59 & +18 & United States & 71 & 76 & +5 \\
\hline & & & & Average (excluding U.S.) & 73.6 & 78.0 & \\
\hline
\end{tabular}

Source: UN Statistics Division, Table 5.G (2004).

Notes: The column for the second year gives the most recent year available between 1995 and 2002 for each country. The definitions and methods of compiling these statistics on wages vary considerably from country to country. Therefore, comparisons between countries are just rough estimates. The trends, however, should be fairly accurate. All of the percentages are based on wages, except for the U.S., which is based on annual earnings. 


\section{Labor Force Participation Rate}

Over the last 50 years the labor force participation rate of women in the U.S. increased from $33.9 \%$ in 1950 to $59.5 \%$ in 2003 (Swanson 2003, p. 39, and Bureau of Labor Statistics, 2004), while the rate for men fell from 86.4\% in 1950 to $73.5 \%$ in 2003 .

Women have become so involved in the economy that they now comprise approximately $47 \%$ of the total labor force. Of any indicator of gender equality, the labor force participation rate of women shows

Table 2: Women's Labor Force Participation Rates

\begin{tabular}{|l|c|c|l|c|c|}
\hline \multicolumn{7}{|c|}{ Least Developed Countries } \\
\hline & $\mathbf{1 9 9 0}$ & $\mathbf{1 9 9 5 / 2 0 0 2}$ & & $\mathbf{1 9 9 0}$ & $\mathbf{1 9 9 5 / 2 0 0 2}$ \\
\hline Afghanistan & 46 & 43 & Lesotho & 47 & 56 \\
\hline Bangladesh & 66 & 56 & Maldives & 20 & 37 \\
\hline Burundi & 91 & 83 & Nepal & 56 & 57 \\
\hline Cambodia & 82 & 74 & Senegal & 25 & 61 \\
\hline Cape Verde & 41 & 44 & Sudan & 50.4 & 29 \\
\hline Ethiopia & 58 & 72 & average & & 55.8 \\
\hline Haiti & 49 & 57 & & & \\
\hline
\end{tabular}

\begin{tabular}{|c|c|c|c|c|c|c|c|c|}
\hline \multicolumn{9}{|c|}{ Developing Countries } \\
\hline & 1990 & $1995 / 2002$ & & 1990 & $1995 / 2000$ & & 1990 & $1995 / 2002$ \\
\hline Algeria & 19 & 7 & Georgia & 56 & 56 & Peru & 29 & 59 \\
\hline Argentina & 29 & 41 & Guatemala & 28 & 23 & Philippines & 48 & 53 \\
\hline Armenia & 63 & 35 & Honduras & 34 & 43 & RepKorea & 47 & 49 \\
\hline Azerbaijan & 52 & 43 & Hong Kong & 47 & 52 & Serbia & 50 & 50 \\
\hline Bahamas & 65 & 66 & Indonesia & 45 & 52 & Singapore & 50 & 56 \\
\hline Bahrain & 29 & 24 & Iran & 21 & 11 & Slovenia & 55 & 52 \\
\hline Barbados & 60 & 62 & Jamaica & 62 & 69 & South Africa & 46 & 46 \\
\hline Belize & 23 & 34 & Jordan & 17 & 22 & Sri Lanka & 45 & 37 \\
\hline Bolivia & 24 & 60 & Kuwait & 38 & 43 & Suriname & 44 & 33 \\
\hline Botswana & 66 & 48 & Macao & 54 & 56 & Swaziland & 40 & 36 \\
\hline Brazil & 44 & 54 & Macedonia & 49 & 42 & Syria & 24 & 24 \\
\hline Chile & 32 & 35 & Malaysia & 45 & 44 & Thailand & 76 & 65 \\
\hline China & 73 & 74 & Martinique & 54 & 55 & Tonga & 36 & 42 \\
\hline Columbia & 46 & 58 & Mauritius & 35 & 41 & Tunisia & 33 & 24 \\
\hline Costa Rica & 33 & 42 & Mexico & 22 & & Turkey & 34 & 27 \\
\hline Croatia & 48 & 45 & Morocco & 39 & 26 & Uruguay & 43 & 47 \\
\hline Cyprus & 48 & 53 & Nicaragua & 40 & 22 & Venezuela & 38 & 55 \\
\hline DomRepblic & 34 & 38 & OccupPalestine & 6 & 10 & UnitArabEm & 29 & 31 \\
\hline Ecuador & 28 & 53 & Oman & 13 & 13 & Zimbabwe & 67 & 65 \\
\hline Egypt & 27 & 20 & Pakistan & 11 & 3 & Aerage & 40.5 & 41.7 \\
\hline El Salvador & 51 & 44 & Panama & 32 & 45 & & & \\
\hline Fiji & 27 & 39 & Paraguay & 51 & 35 & & & \\
\hline
\end{tabular}


Table 2 Women's Labor Force Participation Rates (Continued)

\begin{tabular}{|l|c|c|l|c|c|}
\hline \multicolumn{7}{|c|}{ Countries in Eastern Europe } & \multicolumn{1}{c|}{$\mathbf{1 9 9 0}$} & $\mathbf{1 9 9 5 / 2 0 0 2}$ \\
\hline & $\mathbf{1 9 9 0}$ & $\mathbf{1 9 9 5 / 2 0 0 2}$ & & 57 & 9 \\
\hline Albania & 58 & 50 & Poland & 61 & 3 \\
\hline Belarus & 61 & 46 & Republic of Moldova & 55 & 6 \\
\hline Bulgaria & 60 & 46 & Romania & 60 & 2 \\
\hline Czech Republic & 61 & 51 & Russian Federation & 63 & 3 \\
\hline Estonia & 63 & 51 & Slovakia & 57 & 8 \\
\hline Hungary & 48 & 46 & Ukraine & 59.1 & 9.9 \\
\hline Latvia & 63 & 51 & average & & \\
\hline Lithuania & 60 & 46 & & & \\
\hline
\end{tabular}

\begin{tabular}{|l|c|c|l|c|c|}
\hline \multicolumn{7}{|c|}{ Developed Market Economy Countries } & $\mathbf{9 9 0}$ & $\mathbf{1 9 9 5 / 2 0 0 2}$ \\
\hline & $\mathbf{1 9 9 0}$ & $\mathbf{1 9 9 5 / 2 0 0 2}$ & & 50 & 49 \\
\hline Australia & 52 & 55 & Japan & 34 & 42 \\
\hline Austria & 43 & 50 & Luxembourg & 53 & 54 \\
\hline Belgium & 37 & 43 & Netherlands & 54 & 57 \\
\hline Canada & 59 & 61 & New Zealand & 62 & 70 \\
\hline Denmark & 62 & 74 & Norway & 50 & 54 \\
\hline Finland & 65 & 57 & Portugal & 33 & 41 \\
\hline France & 46 & 48 & Spain & 49 & 76 \\
\hline Germany & 44 & 49 & Sweden & 53 & 48 \\
\hline Greece & 35 & 38 & Switzerland & 58 & 56 \\
\hline Iceland & 66 & 79 & United Kingdom & 49.9 & 60 \\
\hline Ireland & 36 & 48 & United States & & 54.2 \\
\hline Italy & 36 & 36 & Aerage & & \\
\hline
\end{tabular}

Source: United Nations Statistics Division, Table 5.D (2004).

Note: The column for the second year shows the most recent year available between 1995 and 2002 for each country. the largest gain. Although not quite equal yet, the U.S. work force is becoming more diverse by sex, with almost as many women as men working.

Table 2 shows female labor participation rates for 112 countries, grouped according to the U.N. classification of countries. The 1990 average for all 112 countries was $45.8 \%$, and for 1995/2002 it was $46.8 \%$. Worldwide there was no significant change, on average, in female labor force participation rates for the past 10 years. This is similar to the U.S. trend for the same time period, where there was only a slight increase from $58 \%$ to $60 \%$. However, the rate at which women are currently engaged in the labor force is considerably higher in the U.S. than it is worldwide- $60 \%$ compared to an average of $46.8 \%$, or $28 \%$ higher. For a corresponding indicator of gender equality, the percentage of women in the labor force, the difference in current rates is similar- $47 \%$ for the U.S. compared to an average of $39 \%$ for the rest of the world.

It is much more illuminating to look at these data disaggregated by the U.N. classification. For the lowest level of economic development, the least developed countries - the averages for the two years are $50.4 \%$ and $55.8 \%$, respectively. Here there was a modest increase for women, approaching the U.S. level. However, since the male labor force participation rate is very high for the LDCs, the average percentage of women in the labor force is significantly lower (40\%) than it is in the U.S. (47\%).

There was no significant change for the developing countries between the two years listed. The average female labor force participation rate stagnated at about $41 \%$, considerably below the U.S. rate of $60 \%$. This also means that the average percentage of women in the labor force was a low $35.6 \%$ for the developing countries 
The average for the labor force participation rate in developed economies was $49.9 \%$ in 1990 and $54.2 \%$ in 2002. These rates are nearly identical to the rates for the least developed countries. There appears to be no strict relationship between levels of economic development and this indicator of gender equality. There is some difference between the average percentages of women in the labor force for the LDCs and the developed countries, with the former having a current rate of $40 \%$ and the latter having a current rate of $44 \%$.

There does appear to be a stronger connection with the type of economic system, however. In all but two of the countries in Eastern Europe the labor force participation rate for women dropped. On average, the rate fell from $59.1 \%$ to $49.9 \%$, a significant drop of $16 \%$. This parallels a similar drop for the male labor force participation rate in the same countries $(74.1 \%$ to $61.9 \%$, or $16 \%)$. These countries, which have been faring quite poorly by most economic indicators since the end of socialism, are experiencing an overall decline in work by all segments of society. The level of economic development, not measured by GDP or other direct indicators of economic development (as it is for the other three country classifications), but by (former) type of economic system, has had a significantly negative effect on the labor force in these formerly socialist countries. From a similar position to the U.S. in 1990, they have fallen to a considerably lower female labor force participation rate in 2002. Looking at the corresponding indicator of gender equality, the percentage of women in the labor force, however, a different picture emerges. In the Eastern European economies this rate has remained at a high level of 47\% (because both women's and men's labor force participation rates have fallen by the same percentage), equal to the rate in the U.S. This indicator of gender equality shows no connection to levels of economic development.

It is interesting to note that whether a country is predominantly Muslim has a larger effect on labor force participation rates than the level of economic development. If we control for this variable for the least developed countries, we see that the seven non-Muslim countries have average female labor force participation rates of $60.6 \%$ and $63.3 \%$ for the two years. The five Muslim countries, on the other hand, have very low average rates of $36.2 \%$ and $45.2 \%$, respectively. Controlling for this variable for the developing countries gives us similar results. The 47 nonMuslim countries average for the female labor force participation rate is $45.0 \%$ and $47.6 \%$ for the two years, while the sixteen Muslim countries have extremely low average rates of $27.3 \%$ and $23.8 \%$. Women in Muslim countries are poorly integrated into their economies as indicated by their low labor force participation rates (and comprise a correspondingly low $25 \%$ of the labor force).

\section{OCCUPATIONAL SEX SEGREGATION}

A third indicator of gender equality is the degree of occupational sex segregation in an economy. Men and women are not distributed proportionally among the various occupations, with men dominating some occupations, while women dominate others. The degree of occupational sex segregation is an indicator of how unequal this distribution is, of how men and women are integrated in the workplace, and how separated they are by the work that they do.

A standard measure of the degree of occupational sex segregation is the Duncan index of dissimilarity (Duncan and Duncan, 1955). This index gives a number between 0 and 100, which can be conveniently interpreted as the percentage of all females (males) who would have to shift occupations so that the percentage of all males would be equal to the percentage of all females in each occupation. An index of 0 would indicate perfect equality, while an index of 100 would mean that all occupations were either exclusively male or exclusively female. The number for the index is derived from the formula,

$\mathrm{D}=50 \cdot \Sigma\left|\frac{f_{i}}{f_{T}}-\frac{m_{i}}{m_{T}}\right|$, where $f_{i}$ and $m_{i}$ equal the number of females and males, respectively, in occupation $i$, and $f_{T}$

and $m_{T}$ equal the total number of females and males, respectively. Because of perceived shortcomings in the Duncan index of dissimilarity other measures of occupational segregation have been used in several studies (see Charles 1992, Jacobs and Lim 1992, Rawlston and Spriggs 2002, and Bridges 2003). Although some of these measures suggested can be useful in analyzing occupational sex segregation, only the Duncan index will be presented here. Because of its 
clear-cut interpretation and its generality in measuring segregation, the Duncan index is quite useful for understanding segregation.

Table 3 Occupational Segregation for 29 Countries

\begin{tabular}{|c|c|c|c|c|c|c|}
\hline & $\begin{array}{c}\text { Duncan } \\
\text { Index of } \\
\text { Occupational } \\
\text { Segregation } \\
\end{array}$ & $\begin{array}{c}\text { Female } \% \text { of } \\
\text { Total Labor } \\
\text { Force }\end{array}$ & $\begin{array}{c}\text { Female \% of } \\
\text { Male } \\
\text { Earnings }\end{array}$ & $\begin{array}{c}\text { Per Capita } \\
\text { GDP }\end{array}$ & $\begin{array}{c}\text { Urban } \\
\text { Population } \\
\text { (\% of Total } \\
\text { Population) } \\
\end{array}$ & $\begin{array}{c}\text { Infant } \\
\text { Mortality Rate } \\
\text { per 1000 Live } \\
\text { Births } \\
\end{array}$ \\
\hline \multicolumn{7}{|c|}{ Developing Countries } \\
\hline Columbia & 53.3 & 47 & -- & 1924 & 75 & 26 \\
\hline Ecuador & 49.2 & 37.8 & -- & 1444 & 63 & 41 \\
\hline Hong Kong & 50.2 & 44 & 64 & 23499 & 100 & 4 \\
\hline Malaysia & 44.8 & 37.8 & 63 & 3390 & 57 & 10 \\
\hline Philippines & 51.3 & 39 & 80 & 925 & 59 & 29 \\
\hline Slovakia & 62.8 & 46 & -- & 3662 & 57 & 8 \\
\hline Slovenia & 54.0 & 46 & -- & 9109 & 49 & 6 \\
\hline \multicolumn{7}{|c|}{ Eastern European Countries } \\
\hline Bulgaria & 55.1 & 47 & 68 & 1556 & 67 & 15 \\
\hline Czech Republic & 60.9 & 44 & 65 & 5008 & 75 & 6 \\
\hline Estonia & 62.7 & 49 & -- & 3760 & 69 & 9 \\
\hline Hungary & 56.7 & 45 & 71 & 4662 & 65 & 9 \\
\hline Poland & 51.0 & 46 & -- & 4238 & 62 & 9 \\
\hline Ukraine & 54.9 & 49 & -- & 629 & 68 & 14 \\
\hline \multicolumn{7}{|c|}{ Developed Market Economy Countries } \\
\hline Austria & 53.7 & 44 & 68 & 23545 & 67 & 5 \\
\hline Belgium & 50.4 & 43 & 79 & 22242 & 97 & 4 \\
\hline Denmark & 56.1 & 47 & 86 & 29772 & 85 & 5 \\
\hline Finland & 60.1 & 48 & 81 & 23177 & 59 & 4 \\
\hline France & 54.7 & 46 & 78 & 22066 & 75 & 5 \\
\hline Greece & 45.3 & 40 & 82 & 10403 & 60 & 6 \\
\hline Iceland & 57.5 & 47 & -- & 29659 & 92 & 3 \\
\hline Ireland & 55.8 & 41 & 74 & 24824 & 59 & 6 \\
\hline Italy & 46.3 & 39 & -- & 18651 & 67 & 5 \\
\hline Luxembourg & 53.8 & 41 & 72 & 45117 & 92 & 5 \\
\hline Netherlands & 52.2 & 43 & 78 & 23332 & 89 & 5 \\
\hline New Zealand & 49.2 & 45 & 80 & 13662 & 86 & 6 \\
\hline Portugal & 53.4 & 46 & 65 & 10629 & 64 & 6 \\
\hline Sweden & 57.7 & 48 & 91 & 27072 & 83 & 3 \\
\hline Switzerland & 53.1 & 45 & 72 & 33478 & 67 & 5 \\
\hline UK & 53.0 & 45 & 78 & 24502 & 89 & 5 \\
\hline
\end{tabular}

Sources: The Duncan index of dissimilarity was calculated for each country by the author from ILO statistics (International Labor Organization 2004). The percentage of women in the labor force is from United Nations Statistics Division, Table 5.D, 2004, and table entitled "Millennium Indicator", 2004. Female percentage of male earnings is from United Nations Statistics Division, Table 5.G, 2004. Per capita GDP is from United Nations Statistics Division, Estimates of Per Capita GDP in US Dollars, 2004. Urban population and infant mortality are both from United Nations Conference on Trade and Development, Table 7.4A, 2004.

Notes: All of the statistics are for 2000, except for the following countries: Columbia, Hong Kong, and Philippines (all for 2001), Ecuador (1990), Malaysia (1991) and New Zealand (1996). The number of occupations reported varies within a small range for most of the countries. Between 95 and 115 occupations were used for 21 countries, in 4 countries between 76 and 83 occupations were used, and in the remaining 4 countries between 125 and 135 occupations were used.

Table 3 shows values of D (and several indicators of development) for 29 countries. The number of occupations used to calculate $\mathrm{D}$ ranges from 76 to 135 , depending on the data available for each country. This is somewhat disaggregated data, particularly compared to many studies which use only 7 very broad occupational 
classifications. On the other hand, it is more aggregated than some of the data available, as 400 or more occupations are reported for many countries for some years. The advantage of using disaggregated data is that more occupations reveal a more accurate picture of the actual work experience of men and women. It is also true that the value of D declines with more aggregation, making it appear, in studies with highly aggregated data, that there is less segregation than there really is.

The means for the index of dissimilarity are quite similar for the three categories of countries listed. For the developing countries the mean is 52.2, for the Eastern European countries the mean is 56.9, and for the developed market economy countries the mean is 53.3. This would indicate that there may be more segregation in the Eastern European countries, but this is not a very strong conclusion.

Another way to test for a connection between occupational sex segregation and levels of development is to analyze the index $\mathrm{D}$ in relation to particular indicators of development. This was done using per capita GDP, urban population as a percentage of total population, the infant mortality rate, and various measures of educational attainment for the countries listed in Table 3. None of the measures of educational attainment appeared to any have relationship with the index D, so they were dropped from further consideration. I searched for relationships between the remaining three variables within each of the three country classifications, as well as in combined country classifications.

Overall, the results obtained were not particularly promising. There appeared to be no significant relationships between occupational sex segregation and any of the three indicators of development, except when looking at developed economies as a separate group. However, this could be due to the insufficient data set used for the analysis of the Eastern European and developing economies. For the former only 6 countries were considered and for the latter only 7 countries were considered. This is a quite limited data set for the approximately 100 countries classified as developing by the UN, and for the 14 countries classified as Eastern European. On the other hand, the number of countries considered is larger for the developed countries, and is more representative, as 16 of the 27 economies so classified are considered. It is for this group of countries that significant results were obtained.

Table 4 presents the regression equation,

$D=\beta_{0}+\beta_{1}($ per capita GDP $)+\beta_{2}($ urban population $\%)+\beta_{3}($ infant mortality $)$

That attempts to explain the differences in occupational sex segregation among the developed economies. The independent variables are per capita GDP, urban population as a percentage of total population, and the infant mortality rate.

Since the F-statistic is 3.268 (p-value=.059), we are able to reject the hypothesis that all of the $\beta$ parameters are zero. Thus the equation appears to be useful in explaining D. In looking at each independent variables, we see that only the infant mortality rate is significant at the .10 level of significance. Per capita GDP is significant at the .20 level of significance, while the urban population percentage is almost significant at that level. The fairly weak results of this regression are that all three of the independent variables influence occupational sex segregation.

So how does the level of economic development affect occupational sex segregation? Our results show contradictory relationships between the three indicators of development and the index of dissimilarity. First, per capita GDP is positively related to D, meaning that as a country develops (per capita GDP increases), there is an increase in occupational segregation. Second, urban population as a percentage of total population is inversely related to $\mathrm{D}$, meaning that as a country develops (this percentage increases), there is a decrease in occupational segregation. And third, the infant mortality rate is inversely related to D, meaning that as a country develops (this rate decreases), there is an increase in occupational segregation. Thus two measures indicate a positive relation between segregation and development, while the third indicates a negative relation. A similar mixed result, using highly aggregated data, was found by Jacobs and Lim (1992). 
One would expect a negative relation between occupational segregation and economic development. However, both per capita GDP and the rate of infant mortality appear to be positively related to segregation (this result was noted in Charles 1992 and Jacobs and Lim 1992). At least among developed countries there seems to be a counterintuitive (albeit quite weak) positive connection between development and segregation.

Table 4: Regression Equation for Occupational Sex Segregation, Developed Countries

\begin{tabular}{|l|c|c|c|c|c|}
\hline \multicolumn{1}{|c|}{ R .671 } & R Square .450 & $\begin{array}{c}\text { Adjusted R } \\
\text { Square .312 }\end{array}$ & $\begin{array}{c}\text { Standard Error of the } \\
\text { Estimate 3.313 }\end{array}$ & F 3.268 & $\begin{array}{c}\text { Significance F } \\
.059\end{array}$ \\
\hline \multicolumn{7}{|c|}{ Coefficient Estimates } & Standard Error & t & p-value \\
\hline & 66.749 & 9.077 & 7.354 & .000 \\
\hline Constant & .0001865 & .000 & 1.646 & .126 \\
\hline Per Capita GDP & -.09844 & .073 & -1.348 & .203 \\
\hline Urban Population \% & -2.125 & 1.034 & -2.054 & .062 \\
\hline Infant Mortality Rate & \multicolumn{2}{|c|}{}
\end{tabular}

In addition to examining the effect of economic development on occupational segregation, I also checked for a relationship between measures of gender equality. Table 5 presents the results of a correlation analysis between the Duncan index of dissimilarity and the percentage of women in the total labor force for the countries listed in Table 3.

For developing countries alone, developed countries alone, and for Eastern European, developing, and developed countries combined, a quite strong positive correlation was found between these two measures of gender equality. In the first case it was significant at the .10 level, and in the latter two cases it was significant at the .01 level. Since many commentators consider the percentage of women in the total labor force (and the corresponding female labor force participation rate) as not only an indicator of gender equality, but also as an indicator of economic development, this is a similar result to the one above regarding a positive relation between economic development and occupational sex segregation. This counterintuitive result that the more involved women are in the labor force, the more sex segregation there seems to be, is statistically quite strong. It also supports the conclusion that more development leads to more segregation, not less. This does not say, of course, that more women in the labor force causes more segregation, only that they are correlated. There does appear to be something about the way economies have actually developed, however, that results in more occupational sex segregation

Table 5: Correlations Between Occupational Segregation and Female Percentage in the Labor Force

\begin{tabular}{|l|c|c|c|}
\hline & Developing & Developed & $\begin{array}{c}\text { Developing, Developed, \& } \\
\text { Eastern European }\end{array}$ \\
\hline Pearson Correlation & .703 & .742 & .683 \\
\hline Significance & .078 & .001 & .000 \\
\hline
\end{tabular}

\section{CONCLUSIONS}

The trends in both the gender gap in earnings and the female labor force participation rate point to increasing gender equality throughout the world. There are many exceptions to these trends, which appear to have no relation to economic development, but overall the economic position of women in the world seems to be improving.

While the gender gap is larger, on average, in developing economies than it is in developed economies, the female labor force participation rate does not seem to have any relation to economic development. Occupational sex segregation appears to be positively related to some indicators of development, but negatively related to others. Thus we get mixed results concerning gender equality and development: as economies develop, sexual equality improves by some indicators of gender equality, but worsens by other indicators of gender equality. 


\section{REFERENCES}

1. Blau, Francine D. and Lawrence M. Kahn. Gender Differences in Pay. Journal of Economic Perspectives 14, No. 4, fall 2000, pp. 75-99.

2. Bridges, William P. Rethinking Gender segregation and Gender Inequality: Measures and Meanings. Demography 40, No. 3, August 2003, pp. 543-568.

3. Bureau of Labor Statistics. Employment Status of the Civilian Noninstitutional Population 16 years and over by sex, 1971 to date. [www.bls.gov/cps/cpsaat2], extracted 2004.

4. Charles, Maria. Cross-National Variation in Occupational Sex Segregation. American Sociological Review 57, August 1992, pp. 483-502.

5. Duncan, Otis and Beverly Duncan. A Methodological Analysis of Segregation Indexes. American Sociological Review 20, April 1955, pp. 210-217.

6. International Labor Organization. Segregat Data. Published August 2004. [laborsta.ilo.org]

7. Jacobs, Jerry A. and Suet T. Lim. Trends in Occupational and Industrial Sex Segregation in 56 Countries, 1960-1980. Work and Occupations 19, No. 4, November 1992, pp. 450-486

8. Rawlston, Valerie and William E. Spriggs. A Logit Decomposition Analysis of Occupational Segregation: An Update for the 1990s of Spriggs and Williams. The Review of Black Political Economy 29, No. 4, spring 2002, pp. 91-96.

9. Swanson, Paul A. The Persistence of Sexual Discrimination in the Workplace. International Business \& Economics Research Journal 2, No. 7, July 2003, pp. 39-44.

10. United Nations Conference on Trade and Development. Selected Indicators of Development: Population, Health, Environment, Table 7.4A. [stats.unctad.org], extracted 2004.

11. United Nations Statistics Division. Women's Wages Relative to Men's, Table 5.G. [unstats.un.org/unsd/ demographic]. Last updated January 27, 2004.

12. United Nations Statistics Division. Indicators of Economic Activity, Table 5.D. [unstats.un.org/unsd/ demographic]. Last updated January 27, 2004.

13. United Nations Statistics Division. Estimates of Per Capita GDP in US Dollars. [unstats.un.org/unsd/ snaama]. Last updated July 2004.

14. United Nations Statistics Division. Millennium Indicator. [millenniumindicators.un.org/unsd/mi], extracted 2004. 
NOTES 